Данные уровни сформированности ИКТ-компетентности преподавателя иностранного языка четко показывают качественные ступени развития профессиональной компетентности учителя иностранного языка в области ИКТ.

$$
* * *
$$

1. Хуторской А. В. Технология проектирования ключевых компетенций и предметных компетенций [Электронный ресурс] // Интернет-журнал «Эйдос». - 2005. - 12 декабря. - Режим доступа к журн.: M1p://\%\%Гмг. eidos.ru/journal/.

2. Сысоев П.В., Евстигнеев М.Н. Разработка авторских учебных Интернет-ресурсов по иностранному языку // Иностранные языки в школе. 2009. № 2.

3. Сысоев П.В., Евстигнеев М.Н. Методика обучения иностранному языку с использованием новых информационно-коммуникационных Интернет-технологий: Учеб.-метод. пособие. М.: Глосса-Пресс: Феникс, 2010.

4. Евстигнеев М.Н. Компетентность учителя иностранного языка в области использования информационнокоммуникационных технологий // Иностр. языки в школе. 2011. № 9.

\title{
Фадеев О.В., Михалевич А.И. \\ Обзор методов развития локальной мышечной выносливости в беге на длинные и сверхдлинные дистанции
}

Новосибирский военный институт имени генерала армии И. К. Яковлева войск национальной гвардии Российской Федераџии (Россия, Новосибирск)

doi: 10.18411/trnio-01-2022-159

\section{Аннотация}

В статье рассматривается краткая справка про сверхдлинные дистанции, а также особенности и методы подготовки к гонке.

Ключевые слова: физические упражнения, бег, тренировка, силовая подготовка, кроссовая подготовка, ультрамарафон.

\section{Abstract}

The article discusses a brief information about ultra-long distances, as well as the features and methods of preparing for the race.

Keywords: exercise, running, training, strength training, cross training, ultramarathon.

Бег является одним из популярнейших занятий в мире. Занятия этим видом спорта являются важным средством физического воспитания.

В легкой атлетике дистанции различаются по следующим категориям:

- короткие дистанции (спринт);

- средние дистанции;

К бегу на длинные дистанции относятся:

- всё, что длиннее марафона, - и есть бег на сверхдлинные дистанции.

В этом сегменте соревнования проводятся по двум видам забегов:

- $\quad$ на определённое время, где выигрывает тот, кто преодолел наибольшее расстояние;

Из ультрамарафонских забегов, в рамках которых спортсмены бегут определённое время, а не расстояние, IAAF регламентирует бег на 6 и 12 часов, суточный бег, а также многосуточный пробег от 3 до 6 суток.

- $\quad$ на фиксированную дистанцию.

Любительские ультрамарафонские старты проводят на любое расстояние. Официальные соревнования Международной ассоциации сверхмарафона - 50 км, 100 км, 50 
миль (80,4 км) и 100 миль (160,9 км). Хотя мировые рекорды учитываются только при забеге на 100 км, местные федерации вольны регистрировать их и на других дистанциях.

Будучи неолимпийской дистанцией, 100 км не получает большого внимания от регламентирующих организаций. Конечно, эта дистанция входит в число одобренных ИААФ, однако имеет свой руководящий орган - Международную Ассоциацию сверхмарафона (англ. International Association of Ultrarunners, сокращенно IAU). Ассоциация занимается всеми пробегами длиннее марафона.

Что мотивирует бегунов на дистанцию 100 км. На этот вопрос есть ответ у науки. Исследованием занимались учёные из Польши, которые сделали открытие, что ультрабегунов побуждает другой тип мотивации, нежели бегунов на меньшие дистанции.

Опросили 1539 добровольцев из Польши, которые заполнили онлайн-анкету об их мотивации в беге.

Исследование показало, что бегуны на короткие дистанции оценили чувство собственного достоинства, конкуренцию, здоровье и вес в качестве более значимых мотиваторов, чем сверхмарафонцы.

Группа сверхмарафонцев была движима мотивами смысла жизни и принадлежности к группе. Для них путешествия и забеги в группе единомышленников были более ценными, чем соревнование с другими спортсменами.

\section{Особенности подготовки}

Многие бегуны, пробежав марафон, начинают задумываться о дистанции подлиннее, бросая себе вызов. Однако стоит понимать, что использовать типичный марафонский план тренировок для подготовки к ультрадистанции нельзя.

У большинства любителей на преодоление 100 км уйдёт более 12 часов, и вы должны подготовиться к столь долгому времени на ногах. Вот несколько моментов, на которые стоит обратить внимание.

1. Время, а не скорость и километры.

Теперь ваши тренировки должны измеряться временем, а не темпом и накрученными километрами. Тут нет установленных рекомендаций по километражу, но необходимо сделать несколько длительных пробежек, которые составляют 50\% от запланированного времени на 100 км.

2. Длинные пробеги.

Как и в случае подготовки к марафону, делайте длительную тренировку каждые выходные. Как минимум, 50 км хотя бы один раз, а лучше один раз 50 км и несколько по 30 км.

3. Подготовительные гонки.

Тренировки будут качественнее, если заточены под то соревнование, к которому вы готовитесь. В этом вам помогут подготовительные гонки, на которых вы можете попробовать инвентарь в экстремальных условиях с правом на ошибку, побегать по непривычному маршруту, почувствовать атмосферу соревнования. Но не стоит забывать, что это тренировочная гонка, не выкладывайтесь полностью, сохраняя силы для главной цели.

4. Темп гонки.

В ультре первые 30-40 км - это всё еще начало дистанции, и если к этому моменту вы уже чрезмерно напряжены и утомлены, значит, вы бежали слишком быстро.

Тренировочные длительные забеги должны были научить вас подбирать оптимальный темп. Поэтому бегите в темпе, в котором вы чувствуете себя комфортно. Подобно 4-часовой отметке в марафоне, 12-часовая отметка считается хорошим временем для бегунов на 100 км.

5. Подъёмы.

- Бег в гору позволяет добиться большей интенсивности за меньшее время и расстояние. Работа на максимум способствует улучшению показателей МПК, а также “учит” организм перерабатывать лактат, тем самым повышая темп на анаэробном пороге. 
- “Горки" создают большую нагрузку на мышцы - тем самым развивая и укрепляя их. К тому же при беге вверх задействуются и развиваются дополнительные мышцы (в сравнении с равниной), и это способствует большей стабильности при беге.

- $\quad$ Бег в гору - немалая нагрузка на нервную систему.

- Сложные тренировки в гору развивают силу воли. Поскольку нагрузка высокой интенсивности наступает быстрее и раньше, терпеть приходится дольше - и психика адаптируется к этому состоянию.

- Бег наверх с уклоном способствует улучшению техники, ведь бежать в гору, приземляясь на ногу впереди туловища, почти невозможно. Соответственно, уклон как будто заставляет человека приземляться под тазом и на переднюю поверхность стопы, то есть технически правильно.

- Наконец, бег в гору неизбежен при подготовке к соревнованиям по трейлраннингу, когда перепады высот на трассе - обычное дело.

6. Интервальный бег (один из самых эффективных методов).

Это короткие отрезки дистанции, как правило, составляющие диапазон от 200 м до 1600 м. Интервальные тренировки - это бег с чередованием отрезков в анаэробной зоне и коротких отрезков в аэробной зоне. Интервалы можно измерять по-разному: периодами (минутами) или расстоянием (метрами). Количество быстрых интервалов на каждой тренировке, их длина и скорость рассчитываются индивидуально.

Метод интервальной тренировки основан на повторении, т.е. за одну тренировку нужно выполнить определённое количество повторений каждого отрезка. Основная задача интервальной тренировки - как можно дольше продержаться, работая на уровне 95100 МПК (максимальное потребление кислорода). МПК - это количество кислорода, усваиваемое организмом человека за минуту. То есть, способность организма насыщать кислородом мышцы, которые также должны хорошо этот кислород перерабатывать. Чем выше у спортсмена МПК, тем эффективнее его организм будет обрабатывать кислород, который при беге на длинные дистанции является главным источником энергии.

Этот показатель является важным критерием аэробной мощности. Считается, что именно МПК является фактором, лимитирующим и влияющим на работоспособность в циклических видах спорта.

Интервальные тренировки бывают разными, имеется в виду не только количество отрезков, их длина и скорость, но и ландшафтная характеристика (бег по стадиону, бег по пересеченной местности, забегания в короткий подъем и т.д.).

Важно понимать, что одна интервальная тренировка ничего не даст. Лучше вообще не напрягаться, чем напрягаться впустую. Эффект приносит лишь цикл интервальных тренировок в течение месяца.

Восстановление между отрезками лучше всего проводить легкой трусцой. Бег трусцой способствует утилизации молочной кислоты и поддерживает мышцы в эластичном состоянии, что полезно для подготовки к следующему интенсивному отрезку. Активное восстановление в разы быстрее снижает уровень молочной кислоты в мышцах, чем пассивный отдых.

7. Силовая подготовка.

Тут стоит задача развить наибольшую силу сокращения мышц, участвующих при выполнении основного упражнения. К данному направлению обычно относят упражнения, тренирующие максимальную и общую силу.

Существует несколько методов силовой подготовки. К ним относятся:

- тренировка с использованием только собственного веса спортсмена;

- тренировка с использованием свободных грузов;

- тренировка на специальных тренажерах. 
С целью получения максимального результата спортсмену следует учесть преимущества каждого метода подготовки и воспользоваться ими.

\section{0. Отдых}

Недостаток восстановления - основная причина травм, полученных до выхода на старт.

На ультрамарафоне предстоит столкнуться с самыми неожиданными ситуациями, дикими животными, собственными страхами и сомнениями. Вот почему важно со всей ответственностью подойти к предстоящему старту, мысленно проработав все возможные варианты развития событий.

Соблюдая тренировочный план и выполняя рекомендации тренера, общение и перенятие опыта со спорсменами которые уже преодолелю выбранную вами дистанцию вот залог успеха в вашей гонке!

$$
* * *
$$

1. Фадеев, О. В. Теоретические и методические основы развития физического качества "Сила" в физическом воспитании курсантов военного института войск Национальной гвардии Российской Федерации / О. В. Фадеев, Н. Е. Норин. - Текст : непосредственный // Тенденции развития науки и образования. — 2018. № 38. - С. 38-41.

2. Зеличенок В.Б. Лѐгкая атлетика: Энциклопедия. В 2-х томах (2 том). / Зеличенок В.Б., Спичков В.Н., Штейнбах В.Л. Т. 2. - М.: Человек, 2013. - 832 с.

3. Анисимова Е.А. Повышение спортивного мастерства бегунов на короткие дистанции / Е.А. Анисимова, М.А. Козловский - Теория и практика физической культуры. 2010. - № 9. - С. 76-88.

4. Матвеев Л.П. Основы спортивной тренировки. / Матвеев Л.П. - М.: «Физкультура и спорт», 2005г.- 284с.

\section{Шайденко Н.А.}

\section{Гуманизм во взглядах выдающихся педагогов России XIX века}

Институт повышения квалификации и профессиональной переподготовки работников образования Тульской области (Россия, Тула)

doi: 10.18411/trnio-01-2022-160

\section{Аннотация}

В современных условиях трансформации школы особенно актуально звучат идеи педагогов-гуманистов XIX века, которые бывают порой незаслуженно забыты. Целью статьи стал анализ отдельных положений научных теорий К.Д.Ушинского, А.Н.Острогорского, В.П.Острогорского, П.Ф.Каптерева В.П.Вахтерова, Л.Н.Толстого. Знание учителем великого наследия педагогов-гуманистов может оказать существенное влияние на его профессиональное развитие учителя.

Ключевые слова: гуманизм, научная педагогика, развитие личности, нравственное воспитание, детская активность.

\section{Abstract}

In the modern conditions of school transformation, the ideas of humanist teachers of the XIX century sound especially relevant, which are sometimes undeservedly forgotten. The purpose of the article was to analyze certain provisions of the scientific theories of K.D.Ushinsky, A.N.Ostrogorsky, V.P.Ostrogorsky, P.F.Kapterev, V.P.Vakhterov, L.N.Tolstoy. A teacher's knowledge of the great heritage of humanist teachers can have a significant impact on his professional development as a teacher.

Keywords: humanism, scientific pedagogy, personality development, moral education, children's activity.

Основоположник русской научной педагогики Константин Дмитриевич Ушинский считал, что самой основной и выгодной финансовой операцией является организация 